\title{
SCIENCE COMMUNICATION ROLE IN DEVELOPMENT OF COOPERATION BETWEEN UNIVERSITY AND INDUSTRY IN LATVIA
}

\author{
Justīne Vīḳe ${ }^{1}$
}

\begin{abstract}
Transfer of results of scientific research to society for discussion and consumption is nowadays one of scientists' responsibilities. Along with the change of roles of scientific institutions, scientists have also become obliged to distribute results of scientific research, not only within their own community, but also to the part of society that does not consist of specialists in the respective field of research, and that consists of potential consumers of the results of scientific research, including ind ustry as potential commercializers of the research result.
\end{abstract}

The objective of the research was the identification of factors affecting the transfer of results of scientific research to industry (commercialization of science) and the science communication process. Both secondary and primary data were used in the research. Primary data was acquired by semi-structured interviews with experts from industry, university and government.

Several factors affecting the commercialization of science have been identified in the situation of Latvia. There is no motivational system for scientists regarding the organization of science communication in Latvia, but the science communication role is essential for cooperation between university and industry.

UDC Classification: 316 DOI: http://dx.doi.org/10.12955/cbup.v4.809

Keywords: Science communication, commercialization, R\&D, R\&I, RRI, technology transfer.

\section{Introduction}

Introduction of innovative products or services to the market or their commercialization is one of the most important issues for the development of the national economy, expanding cooperation to external markets. Today, the development of innovative products and services is becoming technically more difficult to evolve, and important creators of such products are scientists at universities and research institutes who secure the exchange of knowledge. In the Latvian situation, involvement of scientists in innovative product development can specifically ensure economic growth and development of the national economy. However, for several years after The Innovation Union's performance scoreboard for Research and Innovation, Latvia was recognized as a "modest innovator" in the field of new developments among countries of the European Union; thus it can be concluded that there are several barriers that affect the involvement of science in the development of the Latvian national economy.

Science is at the centre of public debate, especially in debate on the role of science in the creation and implementation of new innovations. Debates are being held on scientific responsibilities, relations with social, political, and economic institutions, as well as on legal and administrative measures to regulate scientific inventions, facilitating their development. These processes involve several parties, including university, industry, society, and government. Science, which is being organized in an economic era of "supply and demand", faces several challenges, partly included in the university's "Third Mission". One of the challenges is provision of communication processes for dissemination of new knowledge; thus it is necessary to identify if science communication is one of the new tools for dissemination of knowledge, to provide a common platform for cooperation between the university, industry, the public, and the government to create new innovations.

\section{Literature review}

Today, one of science's tasks is to participate in promotion of innovation development, thus contributing to the development of the national economy. Historically, scientists have not had a central role in the promotion of innovation development, and their focus has mainly been the development of fundamental sciences, but there is growing emphasis on a scientist's social and economic responsibility. As indicated by Kunda (2011), this marks the transition from isolation from socioeconomical processes to an innovative interaction outside academia. However, this transition does not automatically provide new innovations, because there are also a number of challenges in the organization of research and development (R\&D) processes. Huňady and Orviská (2014) indicate that

\footnotetext{
${ }^{1}$ Justīne Vỉk,e, Rīga Stradiņš University, Latvia, justine.vike@ @rsu.lv
} 
$R \& D$ results in innovations that ensure economic growth, and thus the $R \& D$ process is a precondition for the development of sustainable long-term economic growth. It is often stressed that the R\&D process has to be implemented in cooperation between university and industry, but outside academia there are often new rules and other survival principles. Therefore, it is necessary to determine the roles and responsibilities of the parties involved, not only in collaboration between university and industry, but also in interaction between government and society. The Triple Helix model (Etzkowitz \& Leydesdorff, 2000) theoretically determines the cooperation between university, industry, and government to successfully develop innovation, but because of the growing involvement of society in the development of innovation processes, there is need to use a Quadruple Helix model. Carayannis and Campbell (2012, p.1) point that this is the model "through which government, academia, industry, and civil society are seen as key actors promoting a democratic approach to innovation through which strategy development and decision-making are exposed to feedback from key stakeholders, resulting in socially accountable policies and practices".

As indicated by Jucan and Jucan (2014), the connection between science as an institution and society is very important, because science is a driving force for social, economic, and political progress. Scientific representatives need to inform society about the main results of research that is financed from public funds, thus allowing the concerned part of the public to keep up with scientific progress, however, a closer relationship between science and industry, as promoted by the government, may be called into question with regard to scientific objectivity and the openness of scientific communication (Jucan and Jucan, 2014). It should be noted that contract research paid for by the private sector, does not envisage the transfer of research results to society in the initial stage, but society often gets those results in the form of new products. This raises a new debate on the commercialization of science, for example, in contract research for the private sector or the commercialization of the results of scientific research. There are two diametrically opposed views, one that commercialization of science is necessary, and the other that it is not, explaining that "academic inventions suggests that research and inventive activities are competing for the scientist's limited time, which implies that more inventing comes with less research output" (Buenstorf, 2009, p. 282). Although research and business can compete for the scientist's limited time, the relationship between research, development, and innovation can be effective if bilateral cooperation is ensured. This involves an exchange of knowledge, where the scientist is an expert from the side of research, but the industry is the expert from the side of development, and the cooperation results in innovation and a new product or service. Researchers Callagher, Horst, and Husted (2015) point out that scientists are sometimes skeptical about the growing connection between the university and industry, but that 'New School' scientists participating in commercial activities in science embrace science communication.

Commercialization of scientific developments is directly determined by the scientist's involvement in this process and resultative communication between the parties involved. Under pressure from globalization it is impossible, for example, to carry out commercialization individually, since there are several interested parties involved which have to be informed about the process. The speed of development in science depends on how efficiently scientists communicate and forward scientific results both to professionals and non-professionals who want to introduce these results in the market (Björk, 2007). By disseminating knowledge scientists influence public awareness of the problem, and receive feedback on public interest in the particular field of research. This relationship is defined by the science communication processes. The term 'science communication' "encompasses communication between: groups within the scientific community, including those in academia and industry, [... industry and the public" (Office of Science and Technology, the Trustee of the Wellcome Trust, 2000, p. 12). It should be noted that the concept of science communication is a general one, and so to describe a particular relationship between science and society it is necessary to distinguish between a number of science communication approaches: public awareness of science, public understanding of science, or public engagement with science and technology (PEST). The PEST approach indicates more specifically the public and science cooperation in the creation of new knowledge and developments. Industry and government are also involved in the communication process. As mentioned by Bielak, Campbell, Pope, Schaefer, and Shaxson (2008, p. 201), it is important today to encourage cooperation between different audiences: "science users and decision 
makers, the scientific community, public organizations and individual citizens"; hence science communication can provide the dissemination and use of scientific community knowledge.

Hornig Priest (2008) examined the processes of the global economy which require public access to knowledge. Access to knowledge, in part, is provided by science communication. It is important to look at science communication interaction with technology transfer, since it is one of the main stages of the innovation process, and based on the practical application of knowledge. Rogers (2002) that technology transfer is the process of using information that can be described as a two-way communication process in which, for example, members of the public can actively seek information on possible solutions to their problems from the $R \& D$ processes and involved institutions. Günsel (2015) explains that the value of technology transfer is growing and the effectiveness of technology transfer becomes more dependent on the knowledge communication and sharing process.

The Responsible Research and Innovation (RRI) strategy (Directorate-General for Research and Innovation Science with and for Society, 2015, p. 10) explains how the abovementioned institutions should cooperate to promote innovation development, and stating that "societal actors work together during the whole research and innovation process in order to better align both the process and its outcomes". The RRI key factors are public engagement, gender equality, science education, open access, ethics, and governance (Directorate-General for Research and Innovation Science with and for Society, 2015).

World practice shows that in order to organize the university's 'Third Mission', including commercialization of science in collaboration with industry, Technology Transfer Offices (TTO) are established. Clarysse, Wright, Lockett, Van de Velde, \& Vohora (2005) indicated that in research, collaboration of university and industry was characterized by the involvement of TTO.

In Latvia, TTO started its operations in 2008, during the European Union (EU) fund 2007-2013 planning period, stating that TTO was a structural unit of the university that supports and promotes knowledge and technology transfer activities and is responsible for establishing and maintaining external relations with the private sector, providing information on research activities and experience of the university (The Ministry of Economics of the Republic of Latvia, 2016). The TTO support program was financed from public means until December 31, 2013.

\section{Data and Methodology}

The objective of the research was the identification of factors affecting the transfer of the results of scientific research to industry (commercialization of science) and the science communication process. It is important to identify the role of science communication in the promotion of cooperation between university and industry. Commercialization of science and the science communication process is viewed through the prism of TTO.

The research used both secondary and primary data. Secondary data units were researches, statistical data, and regulations in order to characterize the commercialization of science and the role of science communication in transfer of the results of scientific research to industry. Primary data were obtained from semi-structured interviews with experts. In-depth interviews were conducted with parties involved in the commercialization of science. Data were obtained from 11 informants: scientists, industry representatives, representatives of TTO, The Ministry of Economics of the Republic of Latvia, The Ministry of Education and Science of the Republic of Latvia, and The Investment and Development Agency of Latvia and scientific institutions (universities). During the research, no limitations for data collection and processing were identified.

\section{Results and Discussion}

The research identified a number of factors that affect the commercialization of science (Vìke, 2014). Most of the informants recognized that the factor that most affects the R\&D cooperation is the lack of cooperation between scientists and entrepreneurs. Common trends indicate that cooperative practices are not formed because a number of scientists lack understanding and knowledge of their role in development of the national economy, as well as a lack of contacts with the private sector (especially abroad). In turn, industry lacks innovative manufacturing companies. This trend is also confirmed by the Ministry of Economics of the Republic of Latvia (2016), because the R\&D capacity of Latvian companies is insufficient to provide the creation of new competitive advantages and ensure the long- 
term growth of companies, and because the structure of the Latvian national economy is composed of small and medium-sized enterprises (SME).

As the informants recognized, in practice cooperation between the university and industry is fragmentary; however, this form of cooperation often is not made public because it is a competitive secret. However, in Latvia, during the 2014-2020 EU funds planning period, the operational programme 'Growth and Employment' amendment with an aim to increase private sector investment in R\&D was implemented with four support activities, one of which was the Innovation vouchers for SMEs. The Innovation vouchers provide support for SME innovation capacity building, considering that the Innovation vouchers "aims to overcome an information barrier between SMEs and knowledge institutions" (Organisation for Economic Co-operation and Development, 2010, p.5), also university and other scientific institutions.

One of the instruments mentioned by some of the informants that ensured communication between stakeholders was development of a scientific competence database, which contained scientific services, commercialization offers and partner searches, and examples of good practice (Vīke, 2014). However, it should be stressed that a competence database should be centralized, and not created within the framework of each university and research institute. In Latvia, the centralized information space on scientific achievements that is being created is fragmented; therefore, it may be difficult for the public and industry to obtain necessary information on the achievements and proposals of science. If information does not reach the target audience, there is also no feedback provided, but in this respect it should be noted that today the challenges explored should be aligned with the demands of society and industry. For these processes to be as successful as possible, the policy-makers, together with scientific institutions, should provide a motivational system for the involvement of scientists in the promotion and communication of science. Science communication can be used to create awareness about possible cooperation; thus it can be argued that private funding for R\&D depends on how successful the science communication will be organized. However, in Latvia there is no motivational system for organization of science communication.

Björk (2007) and Vīke (2015) note that scientists are keen to share their knowledge, not always for profit, but also for the acquisition of new contacts and reputation building. Thus, while scientists are engaged in the 'Third Mission', there are other interests besides profit, but the motivational system in universities and research institutes is necessary, to facilitate collaborative practice with industry representatives. As stated by some informants, scientists gained science popularization (not science communication), partly from implementation of research projects financed from EU funds, because during the implementation of the project any publicity activities had to be planned. However, the two activities should be distinguished between project publicity and transfer of the results of supported research projects, because the difference is significant.

Informants also noted that the support instrument that has promoted the recognition of change of the role of scientists is the TTO. The majority of informants noted that the implementation of TTO has also created understanding of the involvement of scientists in the process of commercialization and transfer of the research results to the groups existing outside academia, such as industry.

\section{Conclusion}

From the research it can be determined that science communication is one of the new tools of dissemination of knowledge, and provides a common platform for cooperation between the university, industry, the public, and the government, but in the case of Latvia, during the EU fund planning period for 2007-2013 a systematic science communication strategy was not organized. The research identified a number of barriers to commercialization of science, including the lack of cooperation between scientists and entrepreneurs, scientists lack understanding and knowledge of their role in development of the national economy, the lack of contacts with the private sector and organization of cooperation between the university and industry during the R\&D process. In the case of Latvia, science popularization activities were undertaken, which, in contrast to science communication, do not elicit feedback from the public and industry representatives.

\section{Acknowledgements}

The Paper was supported by the National Research Program 5.2. EKOSOC-LV 


\section{References}

Bielak, A. T., Campbell, A., Pope, S., Schaefer K., \& Shaxson, L. (2008). From science communication to knowledge brokering: the shift from 'science push' to 'policy pull'. In D. Cheng, M. Claessens, T. Gascoigne, J. Metcalfe, B. Schiele, \& S. Shi (Eds.), Communicating science in social contexts, 201-226. DOI: 10.1007/978-1-4020-8598-7

Björk, B. C. (2007). A model of scientific communication as a global distributed information system [Electronic version]. Proceedings of the IATUL Conferences, 1-47. Retrieved March 2, 2016, from http://docs. lib.purdue.edu/cgi/viewcontent.cgi?article=1797\& context=iatul

Buenstorf, G. (2009). Is commercialization good or bad for science? Individual-level evidence from the Max Planck Society. Research Policy, 38, 281-292. DOI:10.1016/j.respol.2008.11.006

Callagher, L., Horst, M., \& Husted, K. (2015). Exploring societal responses towards managerial prerogative in entrepreneurial universities. International Journal of Learning and Change, 8(1), 64-82. DOI: 10.1504/IJLC.2015.069074

Carayannis, E. G., \& Campbell, D. F. J. (2012). Mode 3 knowledge production 1 in quadruple helix innovation systems. Springer Briefs in Business, 7, 1-64. DOI: 10.1007/978-1-4614-2062-0_1

Clarysse, B., Wright, M., Lockett, A., Van de Velde, E., \& Vohora, A. (2005). Spinning out new ventures: a typology of incubation strategies from European research institutions. Journal of Business Venturing, 20, 183-216.

DOI:10.1016/j.jbusvent.2003.12.004

Directorate-General for Research and Innovation Science with and for Society (2015). Report from the Expert Group on Policy Indicators for Responsible Research and Innovation. European Commission.

Etzkowitz, H., \& Leydesdorff, L. (2000). The dynamics of innovation: from National Systems and "Mode 2" to a triple helix of university-industry-government relations. Research Policy, 29, 109-123.

Günsel, A. (2015). Research on effectiveness of technology transfer from a knowledge based perspective. Procedia - Social and Behavioral Sciences, 207, 777-785. DOI: 10.1016/j.sbspro.2015.10.165

Hornig Priest, S. (2008). Linking theory and practice. Science Communication, 30(1), 5-7.

Huňady, J., \& Orviská, M. (2014). The impact of research and development expenditures on innovation performance and economic growth of the country - the empirical evidence. CBU International Conference on Innovation, Technology Transfer and Education, 119-125. Prague, Czech Republic

Jucan, S. M., \& Jucan, C. N. (2014). The power of science communication. Procedia- Social and Behavioral Sciences, 149 , 461-466. DOI:10.1016/j.sbspro.2014.08.288

Kunda, I. (2011). Augstskolu lomas 21. gadsimta sakumā: no autonomijas līdz sabiedriskajai iesaistei. In T. Tisenkopfs, B. Bela, \& I. Kunda (Eds.), Augstskolas reǵionos: Zināšanu un prakses mijiedarbe [Universities in the 21st century : from autonomy to public involvement . In T. Tisenkopfs, Bela B. , \& I. Kunda ( Eds . ), University areas : knowledge and practices of interaction], 40-77, Rìga, Zinātne.

Organisation for Economic Co-operation and Development (2010). Innovation Policy Platform: "Innovation vouchers". Retrieved March 2, 2016, from http://www.oecd.org/innovation/policyplatform/48135973.pdf

Office of Science and Technology, the Wellcome Trust (2000). Science and the Public: A Review of Science Communication and Public Attitudes to Science in Britain. London, Department of Trade, Industry and the Trustee of the Wellcome Trust.

Rogers, E. M. (2002). The nature of technology transfer. Science Communication, 23(3), 323-341.

The Ministry of Economics of the Republic of Latvia (2016). Sākotnējais novērtējums: 1.2.1.specifiskā atbalsta mērḳa "Palielināt privātā sektora investīcijas P\&A" 1.2.1.2.pasākuma "Atbalsts tehnoloǵiju pārneses sistēmas pilnveidošanai" [An assessment: 1.2.1. "To increase private sector investment in R\&D" 1.2.1.2. "Support for technology transfer system development"] Rīga.

Viḳe, J. (2014). Barjeras zinātnisko izstrādṇu komercializēšanas procesā latvijā [Barriers in commercialization process of scientific inventions in Latvia]. Proceedings of the International Scientific Conferences of Faculty of Social Sciences of Daugavpils University. Part I. Issues of Sociology. Daugavpils University, 84-91. 